\title{
Nutrient content of selected edible leafy vegetables
}

\author{
Yahaya Ahmed Iyaka ${ }^{1,}$, , Suleiman Idris ${ }^{1}$, Rahmatallah Adenike Alawode ${ }^{1}$, Bello Usman Bagudo ${ }^{2}$ \\ ${ }^{1}$ Department of Chemistry, Federal University of Technology, Minna, Niger State, Nigeria \\ ${ }^{2}$ Department of Pure and Applied Chemistry, Usmanu Danfodiyo University, Sokoto, Sokoto State, Nigeria
}

\section{Email address:}

iyaka7@yahoo.com (Y. A. Iyaka)

\section{To cite this article:}

Yahaya Ahmed Iyaka, Suleiman Idris, Rahmatallah Adenike Alawode, Bello Usman Bagudo. Nutrient Content of Selected Edible Leafy Vegetables. American Journal of Applied Chemistry. Vol. 2, No. 3, 2014, pp. 42-45. doi: 10.11648/j.ajac.20140203.12

\begin{abstract}
The analysis of proximate and some essential major elements (calcium, magnesium, potassium and sodium) of the leaves of Telfairia occidentalis, Moringa oleifera and Brassica oleracea was carried out using standard methods of food analysis. The result of proximate composition revealed remarkable ash contents of $16.40 \pm 0.5$ and $11.17 \pm 0.2 \%$ for leaves of Telfairia occidentalis and Brassica oleracea respectively, indicating that these two vegetable samples are good mineral sources, since ash content of a plant material is an index of total mineral content. High carbohydrate contents led to a corresponding high energy values of $354.20 \pm 0.7 \mathrm{kcal} / 100 \mathrm{~g}$ (Telfairia occidentalis), $363.60 \pm 1.2 \mathrm{kcal} / 100 \mathrm{~g}$ (Moringa oleifera) and $319.80 \pm 0.7 \mathrm{kcal} / 100 \mathrm{~g}$ (Brassica oleracea). High potassium concentrations of $742 \pm 1.60,667 \pm 3.80$ and $1917 \pm 1.03 \mathrm{mg} / 100 \mathrm{~g}$ obtained for the leaves of Telfairia occidentalis, Moringa oleifera and Brassica oleracea respectively also implied that these vegetables could serve as better potassium sources for hypertensive patients. Recorded Nutrient density (ND) of greater than $100 \%$ recorded for all the elements revealed that the analysed selected vegetables could serve as alternative source of supplement for these mineral elements.
\end{abstract}

Keywords: Vegetables, AAS, Health Benefit, Nutrition, Mineral Composition

\section{Introduction}

Vegetable often mean an edible part of a plant other than a sweet fruit or seed, which typically implies the leaf, stem or root of a plant [1]. Vegetables play an important role in human nutrition; they offer the most rapid and lowest cost source of fibers, minerals and vitamins to the majority of people in developing countries, where they are frequently consumed in relatively small amounts as side dish or relish with the staple foods [2]. The wide variation in color, taste and texture of various vegetables is an interesting additional touch to the meals. Hence, the cultivation and consumption of green leafy vegetables cuts across different races because of their nutritional and health benefits [3].

\section{Main Body}

Telfairia occidentalis is a nutritious vegetable which contains various kinds of nutrients such as starch, protein, carotene, vitamin $\mathrm{B}$, vitamin $\mathrm{C}$ as well as calcium, phosphorus and other mineral substances. Common names for the plant include fluted gourd, fluted pumpkin, and "ugu" by Igbo language in Nigeria. Its therapeutic values in human health include prevention and treatment of diabetes, elimination of radioactive substances, lowering blood sugar and easy digestion [4].

The common name of Moringa oleifera is drum stick and is locally referred to as "zogele" by Hausas in Nigeria [5]. Its leaves could serve as an important source of nutrient for all ages. In Senegal for instance, Moringa oleifera plays significant role as part of normal diet and in the treatment of malnutrition in children, pregnant and nursing women [6]. Brassica oleracea commonly called cabbage is primarily eaten raw or cooked. Cabbage can also be included in dieting programs, as it is a low calorie food. Fresh cabbage juice has been shown to promote rapid healing of peptic ulcers [7].

The aim of this research is to evaluate the nutritional content and the mineral elements of the leaves of Telfairia occidentalis, Moringa oleifera and Brassica oleracea with the view of their being incorporated into the dietary food of the Nigerian nation. 


\section{Material and Methods}

\subsection{Sample Collection and Sample Treatment}

The samples of Telfairia occidentalis, Moringa oleifera and Brassica oleracea used in this study were purchased from central market in Minna, Paiko and Zungeru markets in Niger State, Nigeria. The leaves were separated from the stem, washed with tap water and rinsed with little distilled water to remove the sand and other impurities. They were air dried in the laboratory to remove the surface water, and thereafter oven dried at $80^{\circ} \mathrm{C}$ to a constant weight. The dried leaves were then ground in porcelain mortar, sieved through $2 \mathrm{~mm}$ mesh sieve and stored in polythene bag. The powdered sample was used for both proximate and mineral analysis.

\subsection{Proximate Analysis}

The moisture content of the fresh leaves were determined by drying $5.00 \mathrm{~g}$ of the leaves ( triplicate) in a Gallenkamp oven at $105^{\circ} \mathrm{C}$ until constant weight was attained[8]. Ash content was determined according to the method described by Ceirwyn[9], which involved dry ashing in lenton muffle furnace at $600^{\circ} \mathrm{C}$ until grayish white ash was obtained. Crude protein content was determined by multiplying the value obtained from Kjeldahl's nitrogen by a protein factor of 5.3(a factor recommended for vegetable analysis). Crude lipid was quantified by the method described by AOAC [8] using the soxhlet apparatus and petroleum ether (B.P. $60^{\circ} \mathrm{C}$ $80^{\circ} \mathrm{C}$ ) as a solvent. Crude fiber was determined by acidbase digestion with $1.25 \% \mathrm{H}_{2} \mathrm{SO}_{4}(\mathrm{w} / \mathrm{v})$ and $1.25 \% \mathrm{NaOH}$ (w/v) solutions. Available carbohydrates were calculated by difference i.e. Available Carbohydrates $(\%)=100-$ (crude protein + crude lipid + crude fibre + ash) $[8]$.

Energy $($ calorific $)$ value $(\mathrm{kcal} / 100 \mathrm{~g})=($ Crude lipid $\mathrm{x} 8)+$ (Crude protein x 2) $+($ Carbohydrate $\mathrm{x} 4)$ [10]

\subsection{Samples Preparation for Mineral Analysis}

$6.00 \mathrm{~g}$ of the powdered sample was weighed into a crucible and gently heated over a bunsen burner until it charred. The charred sample with the crucible was transferred into a lento muffle furnace at about $600^{\circ} \mathrm{C}$ and content ashed until grayish white ash was obtained. It was cooled first at room temperature and then in a desiccator. $5.00 \mathrm{~cm}^{3}$ of concentrated $\mathrm{HCl}$ was added and heated for 5 minutes on a hot plate in a fume cupboard. The mixture was then transfer into a beaker and the crucible washed several times with distilled water. The mixture was made up to $40.00 \mathrm{~cm}^{3}$ and boiled for 10 minutes over a bunsen burner. This mixture was then cooled, filtered and rinsed into $100 \mathrm{~cm}^{3}$ volumetric flask and made up mark [9]. The extract was prepared in triplicates.

Sodium (Na) and Potassium (K) were analysed by flame atomic emission spectrophotometer. The concentrations of calcium $(\mathrm{Ca})$ and magnesium $(\mathrm{Mg})$, in the solutions were determined using Atomic Absorption Spectrophotometer, AAS (AAS Analyst 200).

\subsection{Nutrient Density (ND)}

This was estimated using the equation [11] below:

$$
\mathrm{ND}(\%)=\frac{(\mathrm{Np} / \mathrm{Ep})}{(\mathrm{Nr} / \mathrm{Er})} \times 100
$$

Where $\mathrm{Np}=$ nutrient concentration (mineral element in the food),

$\mathrm{Ep}=$ energy supplied by food,

$\mathrm{Nr}=$ recommended daily intakes of nutrient and

$\mathrm{Er}=$ recommended energy intake.

\subsection{Data Analysis}

Data were generated in triplicates and the mean standard deviation determined according to Steel and Torrie [12].

\section{Results and Discussion}

\subsection{Proximate Composition}

As indicated in Table 1, the moisture contents of $5.90 \pm 0.2, \quad 7.60 \pm 0.3$ and $9.78 \pm 0.4 \%$ obtained from the studied vegetables were very low. Ash content for the leaves of Moringa oleifera was low when compared to $11.17 \pm 1.2$ and $16.40 \pm 0.5 \%$ recorded for Brassica oleracea and Telfairia occidentalis leaves respectively. Since ash content of a plant material is an index of total mineral content it implies that Brassica oleracea and Telfairia occidentalis leaves are better mineral sources.

Table 1. Proximate composition of the studied leaf samples

\begin{tabular}{|c|c|c|c|}
\hline \multirow[b]{2}{*}{ Parameter } & \multicolumn{3}{|c|}{ Concentration (\% Dry weight) ${ }^{a}$} \\
\hline & $\begin{array}{l}\text { Telfairia } \\
\text { occidentalis }\end{array}$ & $\begin{array}{l}\text { Moringa } \\
\text { oleifera }\end{array}$ & $\begin{array}{l}\text { Brassica } \\
\text { oleracea }\end{array}$ \\
\hline Moisture content ${ }^{\mathrm{b}}$ & $5.90 \pm 0.2$ & $7.64 \pm 0.3$ & $9.78 \pm 0.4$ \\
\hline Ash content & $16.40 \pm 0.5$ & $3.67 \pm 0.6$ & $11.17 \pm 0.2$ \\
\hline Crude Protein & $31.19 \pm 4.6$ & $27.71 \pm 4.3$ & $34.20 \pm 1.2$ \\
\hline Crude Fiber & $2.55 \pm 0.8$ & $9.44 \pm 1.6$ & $13.99 \pm 1.4$ \\
\hline Crude Lipid & $9.96 \pm 0.6$ & $9.32 \pm 0.6$ & $11.91 \pm 2.2$ \\
\hline Carbohydrate & $34.95 \pm 0.4$ & $42.21 \pm 4.5$ & $18.96 \pm 4.4$ \\
\hline Energy $(\mathrm{kcal} / 100 \mathrm{~g})$ & $354.20 \pm 0.7$ & $363.60 \pm 1.2$ & $319.80 \pm 0.7$ \\
\hline
\end{tabular}

${ }^{\mathrm{a}}$ The data are mean value \pm standard deviation (SD) of triplicate

${ }^{\text {b}}$ Value expressed as \% wet weight

Crude protein content is within the range of $27.71 \pm 4.3$ and $34.20 \pm 1.2 \%$ which is high when compared to $3.33 \pm 0.07 \%$ indicated for the leaves of Ocimum gratissimum [13]. This revealed that samples analysed are moderate protein sources. The crude fiber content in the leaves of this study is low but can still make sigficant contribution to dietary intakes since fiber lowers the body cholesterol level, thus decreasing the risk of cardiovascular diseases [14]. Though low, the concentration of lipid 
ranged from $9.32 \pm 0.6$ to $11.91 \pm 2.2 \%$, which is in agreement with the general observation that leafy vegetables are low lipid containing foods that plays significant role in avoiding obesity [15].

Main function of carbohydrate in the body is for energy supply. Ifon and Bassir [16] observed that leafy vegetables may not be an important source of carbohydrates due to their consumption along with other carbohydrate rich food such as cereals. The calorific values of most vegetables are low. The values of $354.20 \pm 0.7, \quad 363.60 \pm 1.2$ and $319.80 \pm 0.7 \mathrm{Kcal} / 100 \mathrm{~g}$ for the leaves of Telfairia occidentalis, Moringa oleifera and Brassica oleracea respectively were similar to $300.94 \pm 5.31 \mathrm{kcal} / 100 \mathrm{~g}$ reported for water spinach leaves by Umar et al., [17].

\subsection{Mineral Content}

Proximate and mineral composition of the leaves of Telfairia occidentalis, Moringa oleifera and Brassica oleracea are presented in Table 2. Potassium concentration in the samples analysed ranged from $667 \pm 3.80 \mathrm{mg} / 100 \mathrm{~g}$ to $1917 \pm 1.03 \mathrm{mg} / 100 \mathrm{~g}$. Sodium is required by the body to regulate blood pressure and blood volume. Sodium content was within $98 \pm 3.0$ and $170 \pm 2.0 \mathrm{mg} / 100 \mathrm{~g}$ range which is remarkably lower than $805.60 \pm 0.01 \mathrm{mg} / 100 \mathrm{~g}$ reported for the leaves of Balanites aegyptiaca [18]. Sodium to potassium ratio of less than one has been recommended for the prevention of high blood pressure [19]. Thus, the consumption of the selected leafy vegetables in this study could probably serve to reduce high blood pressure diseases in the human body, due to the less than one value obtained for their $\mathrm{Na} / \mathrm{K}$ ratio (Table 2 ).

Table 2. Mineral composition of the selected leaves studied

\begin{tabular}{llll}
\hline \multirow{2}{*}{ Mineral Elements } & \multicolumn{3}{c}{ Concentration (Dry matter) ${ }^{\mathbf{a}}$} \\
& $\begin{array}{l}\text { Telfairia } \\
\text { occidentalis }\end{array}$ & $\begin{array}{l}\text { Moringa } \\
\text { oleifera }\end{array}$ & $\begin{array}{l}\text { Brassica } \\
\text { oleracea. }\end{array}$ \\
\hline $\mathrm{K}(\mathrm{mg} / 100 \mathrm{~g})$ & $742 \pm 1.60$ & $667 \pm 3.80$ & $1917 \pm 1.03$ \\
$\mathrm{Na}(\mathrm{mg} / 100 \mathrm{~g})$ & $98 \pm 3.0$ & $132 \pm 1.10$ & $170 \pm 2.0$ \\
$\mathrm{Ca}(\mathrm{mg} / 100 \mathrm{~g})$ & $519 \pm 1.90$ & $906 \pm 8.60$ & $387 \pm 8.0$ \\
$\mathrm{Mg}(\mathrm{mg} / 100 \mathrm{~g})$ & $425 \pm 9.0$ & $333 \pm 9.0$ & $237 \pm 1.80$ \\
$\mathrm{Na} / \mathrm{K}$ & 0.13 & 0.20 & 0.1 \\
\hline
\end{tabular}

Calcium plays an important role in building strong as well as in the keeping healthy bones and teethes at both early and later life. $519 \pm 1.90,906 \pm 8.60$ and $387 \pm 8.0$ $\mathrm{mg} / 100 \mathrm{~g}$ are the calcium concentrations in Telfairia occidentalis, Moringa oleifera and Brassica oleracea leaves respectively. The leaves of Telfairia occidentalis, Moringa oleifera and Brassica oleracea contain 425 \pm 9.0 , $333 \pm 9.0$ and $237 \pm 1.80 \mathrm{mg} / 100 \mathrm{~g}$ as $\mathrm{Mg}$ concentration which is high when compared to $79-107 \mathrm{mg} / 100 \mathrm{~g}$ found in Ipomoea batatas leaves [20].

Nutrient density (ND) is the index of nutritional quality used to evaluate the nutritional significance of mineral elements and food materials with ND of $100 \%$ supply the nutrient needed in the same proportion as the calorie needed. The obtained ND values for vegetables of this study (Table 3) showed that all the mineral elements in the samples analysed have nutrient density greater than $100 \%$, which further confirmed that the leaves of Telfairia occidentalis, Moringa oleifera and Brassica oleracea could serve as source of mineral element supplements.

Table 3. Nutrient density of mineral elements in the leaves studied

\begin{tabular}{lllll}
\hline Minerals & RDA & \multicolumn{3}{c}{ Nutrient density (\%) } \\
& $(\mathbf{m g})$ & $\begin{array}{l}\text { Telfairia } \\
\text { occidentalis }\end{array}$ & $\begin{array}{l}\text { Moringa } \\
\text { oleifera }\end{array}$ & $\begin{array}{l}\text { Brassica } \\
\text { oleracea. }\end{array}$ \\
\hline $\mathrm{K}$ & 2000 & 314 & 275 & 899 \\
$\mathrm{Na}$ & 500 & 166 & 218 & 319 \\
$\mathrm{Ca}$ & 1200 & 366 & 623 & 303 \\
$\mathrm{Mg}$ & 350 & 1028 & 785 & 635 \\
\hline
\end{tabular}

\section{Conclusion}

The high ash contents obtained for the leaves of Telfairia occidentalis and Brassica oleracea make them better mineral sources than Moringa oleifera leaves. Crude protein contents were quite high in the studied samples, thus suggesting that they can serve as a protein supplement. High potassium content was recorded for Brassica oleracea which makes it better potassium source especially for hypertensive patient since potassium reduces high blood pressure. The proximate and mineral elements results obtained from the analyses of Telfaira occidentalis, Moringa oleifera and Brassica oleracea indicate that consumption of these vegetables in adequate amount could contribute immensely towards meeting human nutritional need for normal body growth and adequate protection against diseases caused by malnutrition.

\section{References}

[1] Omale J.,and Ugwu C.E. Comparative Studies on the Protein and Mineral composition of some selected Nigerian Vegetables. 2011; 5(1):22-25.

[2] Iyaka Y.A. Concentration of $\mathrm{Cu}$ and $\mathrm{Zinc}$ in some fruits and vegetables commonly available in North-Central zone of Nigeria. Electronic Journal of Environmental,Agricultural and food chemistry. 2007; 6(6);2150-2154.

[3] Schmidt D.R. Comparative yield and composition of eight tropical leafy vegetables grown at two soil fertility levels. Agronomy Journal. 1994; 63: 559.

[4] Hongyu L. The analysis of the nutritional value of pumpkin. Ezine_Articles.com.20122011. Retrieved on $1^{\text {st }}$ May, 2011.

[5] Jed W.F. Moringa oleifera: A Review of the Medical Evidence for Its Nutritional,Therapeutic, and Prophylactic Properties. Part 1.Johns Hopkins School of Medicine, Department of Pharmacology and Molecular Sciences, Lewis B. and Dorothy Cullman Cancer Chemoprotection Center, 725 N. Wolfe Street, 406 WBSB, Baltimore, Maryland, USA 21205-2185; 2005. 
[6] Price M.L. The Moringa Tree, ECHO Technical Note. Educational Concerns for Hunger Organization, N. Ft. Meyers, FL (Revised 2000 by Kristin D.); 1985.

[7] Duke J.A., and Ayensu E. S. Medicinal Plants of China Reference Publications, Inc., 865; 1985.

[8] AOAC. Official Methods of Analysis. Washington DC Association of Official Analytical Chemists. 14th Edition: $140-147 ; 1990$.

[9] Ceirwyn S.J. Analytical Chemistry of food. Chapman and Hall Publisher, London, 76-77; 1995.

[10] Emmanuel I.A., and Folasade O.O. Chemical composition and functional properties of leaf protein concentrates of Amaranthus hybridus and Telfairia occidentalis. Agri. and Bio. J. of North Ameri. 2011; 2(3): 499-511.

[11] Cole A.H. Energy expenditure and energy requirements in Nigeria. Nig. J. of Nutri. Scie.1980; 1(2): $204-207$

[12] Steel R.G.D. and Torrie J.H. Principles and proce-dures of statistics - a biometrical approach, 3rd Edition, Me-Graw Hill Book CoY. NY, USA; 1980.

[13] Idris S., Iyaka Y.A., Ndamitso M.M., and Paiko Y.B. Nutritional Composition of the Leaves and Stems of Ocimum Gratissimum. Journal of Emerging Trends in Engineering and Applied Sciences. 2011; 2(5):801-805.

[14] Hanif L., Prakash D., and Pal M. Nutritional and anti nutritional comparison of vegetable and grain Amaranthus leaves. Journal of the Science of Food and Agriculture. 2006; 57: 573-585.
[15] Lintas C. Nutritional aspects of fruits and vegetables consumption. Options Mediterraeennes. 1992; 19:79-87.

[16] Ifon E.T., and Bassir O. The nutritive value of some Nigerian leafy vegetables- parts 2: The distribution of proteins, Carbohydrates (including ethanol-soluble simple sugars), Crude fat, Fibre and Ash. Food Chemistry. 1980;5: 231-235.

[17] Umar K.J., Hassan L.G., Dangoggo S.M., and Ladan M.J. Nutritional composition of water spinach (Ipomoea aquatic Forsk) leaves, Journal of Applied Science. 2007; 7(6):804807.

[18] Idris S., Ndamitso M.M., Yisa J., Dauda B.E.N., and Jacob J.O. The proximate and mineral composition of the leaves and stems of Balanites aegyptiaca. International Journal of Applied Biological Research. 2010; 2(1):76-87.

[19] FND. Food and nutrition board, Institute of Medicine. National Academy of Sciences. Dietary reference Intake for Energy, Carbohydrate, Fibre, Fat, Fatty acids, Cholesterol, Protein and amino acid (micronutrients); 2002.

[20] Ishida H., Suzuno H., Sugiyama N., Innami S., Todokoro T. and Maekawa A. Nutritional evaluation of chemical components of leaves, stalks and stems of sweet potatoe(Ipomoea batatas) leaves. Food Chemistry. 2000; 68:359-367. 